\title{
藻場の介形虫類の機能形態 特に生殖行動との関連について—
}

\author{
神 谷隆 宏
}

(金沢大学理学部地学教室)

\author{
Functional Morphology of Ostracoda in Seagrass Beds \\ - with Special Reference to the Copulatory Behavior
}

TAKAHIRO KAMIYA

\begin{abstract}
KAMIYA, TAKAHIRO (Department of Earth Sciences, Faculty of Science, Kanazawa University). 1989. Functional Morphology of Ostracoda in Seagrass beds — with Special Reference to the Copulatory Behavior. Benthos Research (Bull. Jap. Assoc. Benthology), 35/36 : 75-88.

A set of related species living in different habitats is suitable to evaluate various adaptive characters to habitats, particularly in a such set where plural genera are recognized. Functional morphology of ostracods, especially their carapace shape, is thoroughly studied here through observation of the different mode of behavior between phytal and bottom-dwelling species of Loxoconcha and some other genera in seagrass beds. The phytal species living on smooth leaf-surface of seagrasses such as Zostera have vertically compressed carapaces with blade-shaped ventral part. On the contrary, the bottom-dwelling species in Zostera beds are cubic with flat ventral plane or streamlined in the carepace shape. The characteristics of the phytal is directly related to the style of copulation which is adopted (ventral-to-lateral position) to do not slip down to the bottom during copulation. The bottom-dwelling species copulate in ventral-to-ventral position and their shapes of the ventral part seem to be controlled by not the copulation style but the mode of behavior whether more epibenthonic or inbenthonic. Functional characters of soft parts, such as sexual organ and the tip of the appendages, are also documented, and the significance of analyses of "breeding", in general, is emphasized to understand Ostracoda.
\end{abstract}

\section{はじめに}

丘浅次郎は生物の本質を「食うて生んで死ぬ」と表 現した。これは古生物においても同様な意味を持ち, 過去の生物の生活様式を探求する古生態学においては 「食い方」の重要性に早くから注意が払われ，多くの 研究がこの観点から古生物を理解しようとしてきた。 機能形態学におけるパラダイム法の先駆的な研究とし
て有名な RUDWICK (1961) の論文は, ペルム紀の腕足 類 Prorichthofenia の特異な形態を,食物の攝取に関す るパラダイムで説明しようとしたものである（もっと も，その後 GRANT（1975）が多くの標本を再検討し, その形態は RUDWICK のいう摂食様式のパラダイムで は説明出来ないことが分かったが).一方，「生み方」 については「いかに子孫を多く残すか」の問題として， 例えば更新世のオオツノジカのオスに奇異なほど巨大 
なツノが発達した理由を性淘汰に帰したり（GOULD， 1974), r-K 戦略などの個体群生態の面からも研究され てきた。しかしながら，広い意味での「生み方」に含 まれるであろうが, 生むための前行為である「交尾の 仕方」自体に取り組む研究は疎んじられてきた。これ は化石によく残りうる生物で交尾をするものが少ない ためであろう。しかし，もし，化石として産した生物 が，どこで，どんなスタイルで交尾していたかなどを その姿形から推定できるとしたら面白い. 生物の本質 のひとつを化石記録にとどめていることになるからで ある。ここで紹介する介形虫はそんな生物のひとつに 挙げられそうなことがわかってきた。

介形虫 (Ostracoda) は大きさ $1 \mathrm{~mm}$ 前後の小型甲殼類 で，深海から汽水域，池や沼，水溜りまで，水のある 多様な環境に生息している，底生の種類の多くは石灰 質の背甲 (一般に殸と呼ぶ)を有し，カンブリア紀 (約 5 億数千万年前）に出現して以来これが化石として地 層中から普遍的に産するため，石油探査の際の古環境 解析や時代決定などに広く利用されてきた。近年，あ る種の背甲表面の網目模様が表皮細胞の配列に対応し ている例 (OKADA，1981，1982a，b) や，同種内の背 甲の多型や変異が塩分濃度や底質などの物理・化学的 環境の違いを如実に反映している例（ROSENFELD \& VESPER, 1977 ; DANIELOPOL et al., 1988 ; CARBONEL \& HOIBIAN，1988）など，殼形態が生物学的に興味深 い情報を含んでいることが指摘された「海のショウジ ヨウバエ」と呼ぶ研究者もあり, 進化古生物学の材料 としてもきわめて有用性, 将来性の高い分類群といえ る. しかしその一方で現生介形虫の生活様式といった ベイシックな生態学的側面は十分把握されてきたとは いいがたい，特に，海の中に潜って生活場所を直接観 察したり，そこで採った海産種の行動を顕微鏡下で観 察するといったことは, この生物の生態学的研究が主 として寒海の北西ヨーロッパを中心に行われてきたこ ともあってか，ほとんど手がつけられずにきた。ここ 数年筆者は三浦半島油壼湾のアマモ場の介形虫を詳細 に調査し，介形虫が微生息場所の特質にうまく適応し た生活様式をもっていることを報告してきた。介形虫 は, 個体レベルの行動,形態においても (KAMIYA, 1988 a)，個体群レベルの生態においても（KAMIYA，1988 $b, c)$, 器官レベルの, 感覚子の分布と形態においても （KAMIYA，in press）生息場所への見事な適応を示 す。本稿では，介形虫が微生息場所の物理的特徵にう まく合った行動様式，特に「交尾様式」を持っている こと,そして背甲や軟体部の形態がその行動様式に実
にうまくマッチしていることを，既に紹介した油壶湾 のアマモ場の観察結果（KAMIYA，1988a）を中心に， 他の藻場の調査結果をまじえて紹介する。「生殖」な かでも「交尾」という観点は，一般的に介形虫のオス が体の三分の一，種によっては半分近くを占める大き な生殖器をもつことからも示唆されるが，介形虫の実 体, 介形虫とはどんな生物か，ということを理解する ためのきわめて重要なアプローチなのである。

\section{油㙪湾藻場の介形虫群集}

生息環境と介形虫の種類との関連については既に多 くの研究がある，例えば BENSON（1959）は幅，奥行 きとも約 $15 \mathrm{~km}$ の開いた内湾である Todos Santos 湾と その周辺を調へ， Estuarine, Rocky tide pools, Salt water lagoon \& marsh, Shallow shelf (coarse sands), Shallow shelf (fine sands and silts), Deep water の 6 つの環境にそれぞれ特有な群集が産するこ とを報告し，同時に生息場所と壳の形の関連について も言及した。またWILLIAMS（1969）はもう少しミク ロなスケールでイギリス西部 Anglesey 島の潮間帯の 海藻と海浜堆積物を調べ, 海藻（ヒバマタ, アオノリ, コンブなど）に主に見つかる種類（Xestoleberis， Paradoxostoma）と，底質上に主に生息する種類 (Leptocythere, Polycope) とがあるが, 海藻起源のデ トリタスの多い境界付近ではそれらが混合して見つか ることを報告した。

これらの先駆的研究の結果，いまや重要な問題は, そうやって棲み分けている介形虫の形態や行動や個体 群動態が生息場所とどのような必然的関連性を持って いるか，あるいはもっていないかをはっきりさせるこ とである。ここでまずとりあげたアマモ場は以下に述 べるように，この問題を論じるのに都合の良い自然の 実験室ともいえるメリットをもっている。

アマモ (Zostera marina) は北半球に最も繁栄して いる海草のひとつで, 水深 $1 \mathrm{~m}$ から数 $\mathrm{m}$ の砂底また は砂泥底に, 長さ約 $1 \mathrm{~m}$, 幅約 $1 \mathrm{~cm}$ の薄い数枚の葉か ら成る株が地下茎でつながり群落をなす。葉中の細胞 間隙が酸素でみたされているため海底に垂直に立ち， 波間に摇れる姿から英語では eel grass と呼ばれる。 軟らかい底質ゆえ，固着性の海藻が定着し生育するこ とのない潮下帯直下の砂泥底において貴重な海中林と なるため多くの葉上小動物のすみかとなり，またこの ため稚魚などの育成場として水産学的にも重要な意義 を持つ。 


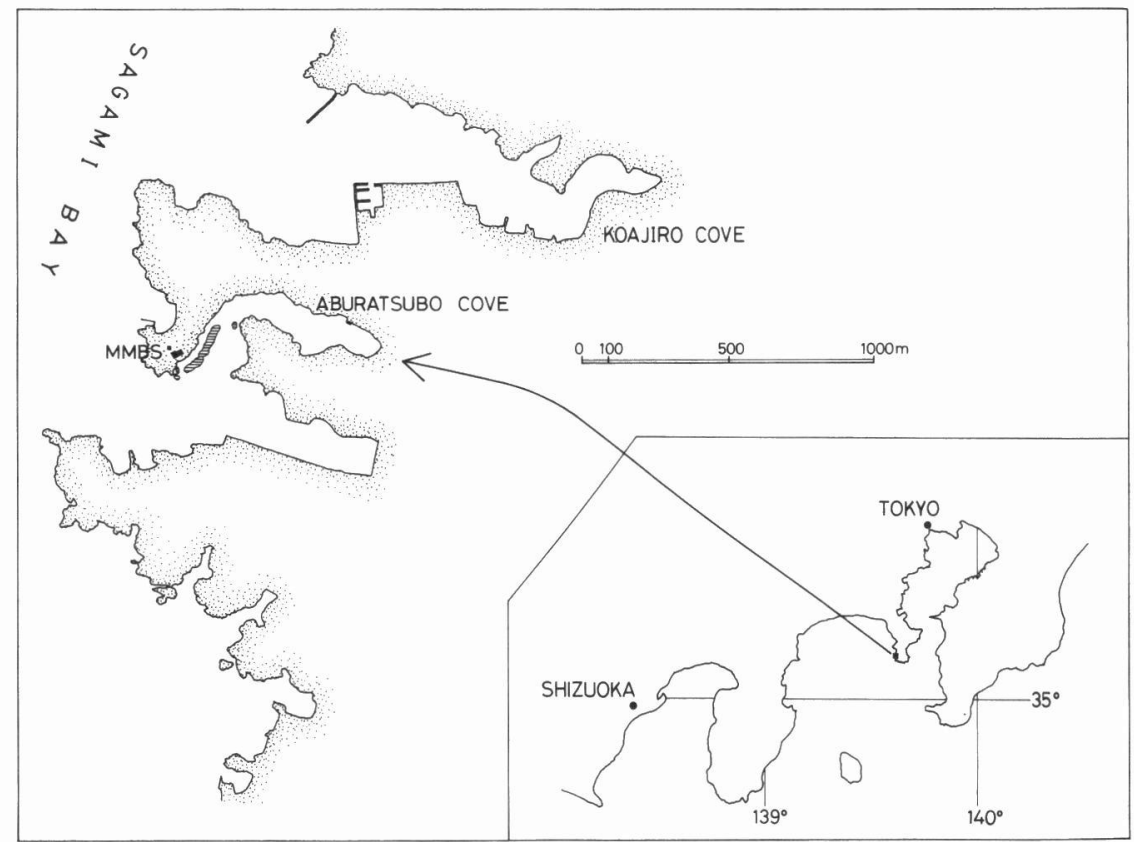

図 1 海劽湾位置図. 斜線部は湾内のアマモ場の分布を示す. MMBS : 東京大学理学部付属三崎臨海実験所 (KAMIYA，1988aより引用)

アマモ場が介形虫の生息場所への適応を調べる環境 としてすばらしいのは，たかたか垂直に数十 cm離れた だけで，海底にほぼ垂直に立つ滑らかな葉面(しかも それは始終摇れる）と，うすいデトリタス層に被われ た海底砂泥表層という, 安定性の点からは対照的な, しかしどちらにも介形虫の棲みうる生息場所を提供す る点にある。これは他の岩礁地の海藻場では得られな いセッティングである。水深や水温, 水質などについ ては同条件であるため, 主として棲み場所の形状（物 理的性質）の違いが介形虫の種類, 形態, 生態に直接 与える影響を見積るのに最適なわけである。

三浦半島油劽湾のアマモ場（図 1，2）に生息する 介形虫を約二年半にわたり, 毎月一回から二回, 葉と 底質表層とを丁寧に採り分けて調べたところ, それぞ れに独立した群集が見つかった(図 3 )。葉上には 8 種 類, 底質表層には10種類が生息しており，両方に共通 するのは Xestoleberis hanaii だけである(個体数はど ちらにも少なく，この種の主な生息場所はむしろ岩礁 地の石灰藻にある). 葉上群集の中でアマモ固有種は優 占種Loxoconcha japonicaだけであり, Paradoxostoma spp. はアオサ, コンブなどの海藻類にも生息し, Loxocorniculum mutsuense, Hemicytherura

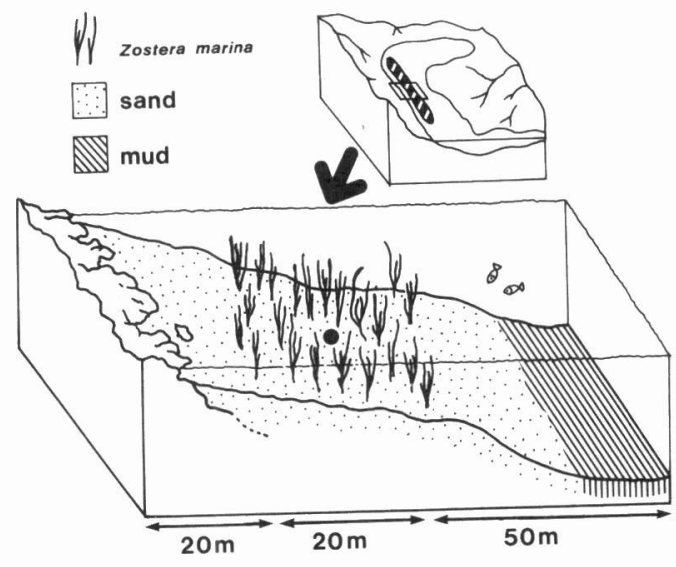

図 2 試料採取地点（黒丸）

kajiyamai はむしろ石灰藻類に, Aurila munechikai はホンダワラ科の海藻に多産する。一方, 砂底群集の 優占種は Loxoconcha uranouchiensis であり, Aurila uranouchiensis, Callistocythere rugosa などがこれに 続く. Keijella bisanensis, Loxoconcha bispinosa 2 種はむしろ湾央のやや深い泥底に多産する。ところで， 


\section{ZOSTERA PHYTAL FAUNA}

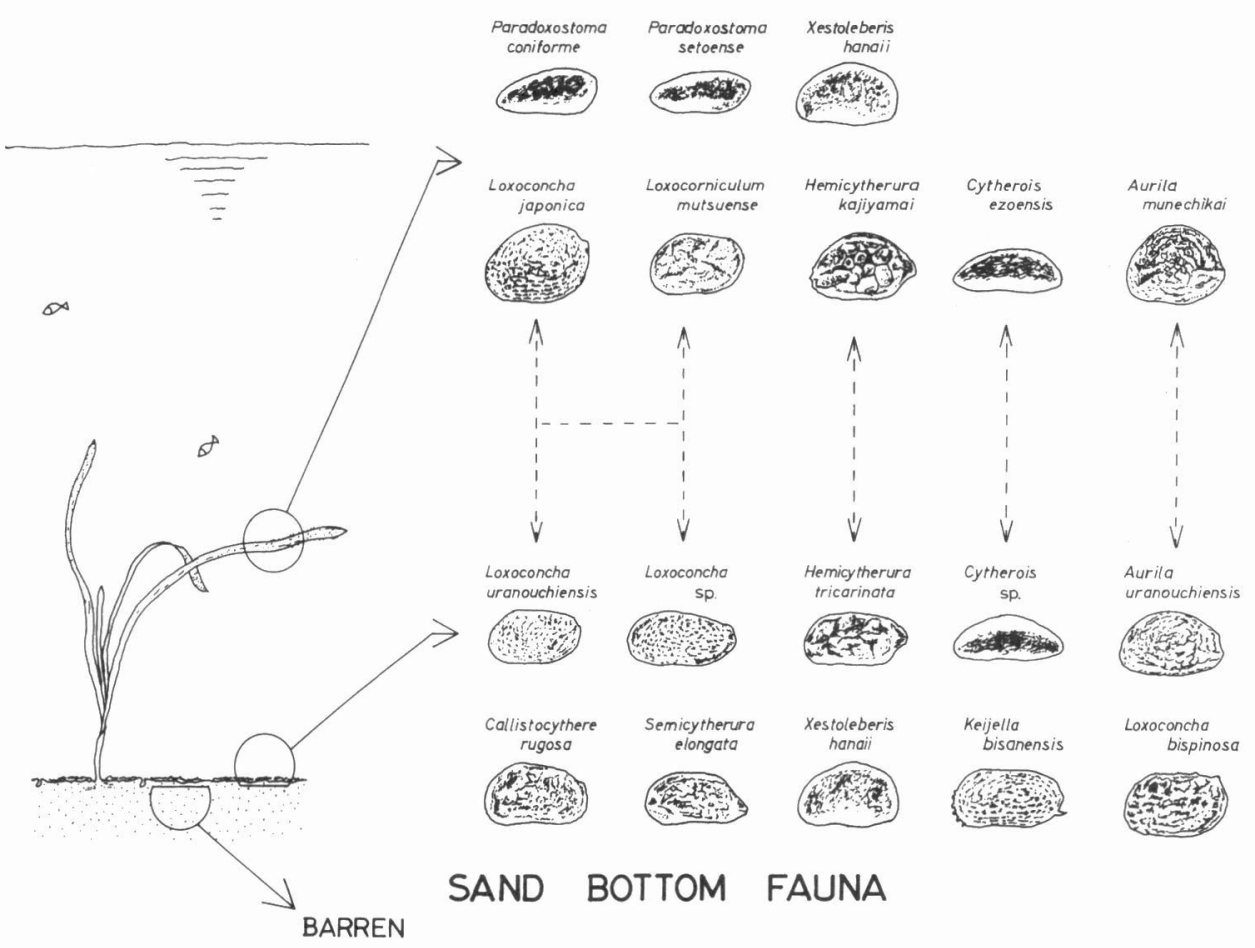

図 3 アマモ場に生息する二つの介形虫群集。矢印は葉上，砂底群集間にみられる同属異種の対応関係を示 す. (KAMIYA，1988aを修正)

このふたつの群集の間には面白い対応関係がみられる。 葉上種Loxoconcha japonicaの対として砂底種 $L$. uranouchiensis があり, 葉上種 Hemicytherura kajiyamai に対し砂底種 H. tricarinata があり, 同様に Cytherois ezoensis と C. sp., Aurila munechikai と A. uranouchiensis, Loxocorniculum mutsuense と Loxoconcha sp. という, 同属異種, もしくは近縁属の ペアがふたつの群集間に五組もみつかる。この, いわ ば「平行群集」は，それぞれの生息場所に対する適応 をみつもるのにすこぶる都合の良いものである。各々 の群集内に共通する形質, 生態的特質は系統によりも たらされたものではなく, 生息場所への適応の過程で 出現した可能性が強いのであるから，この点を徹底的 に調べればよいのである。

\section{葉上種, 砂底種の形態と行動}

背甲の形態を観察した結果，海底底質上に生息する ものは腹部が平坦かあるいはやや凸に膨れるかしてお り, 全体が細長いこと(円柱, 三角柱, 直方体を横に したような形)，一方，アマモ葉上に住むものは腹部が くさび状に尖り，横から見た場合丸いこと（アサリや ハマグリなどの二枚貝を立てたような形)が判った(図 4,5 ). この特徵は, 同属異種のぺアを成す種類に も，片方の群集に単独にみつかる属の種にもはっきり と認められる。背甲の形は従来側面から観たものが記 載され図示されてきたが,これに加え, 頭または尻の 方からの図示は腹部の形態を明瞭に示す場合には実に 有効である、この葉上種, 砂底種の背甲形態の相違は 同属異種のペアの場合，発生段階で徐々に表れだし， 成体となる最終脱皮時に完成する。その一例として図 6 に葉上種 Loxoconcha japonica, 砂底種 L. ura- 
nouchiensis の個体発生を示した。 L. japonicaのオス は最終脱皮後にやっとこの種の特徵であるよく膨れた 背甲後部を有するようになるが，ここは最終脱皮時に 付加した長い柄をもつ巨大な生殖器が収納されている (図 7 ).これらの観察結果は殼の形態的特徵が成体時 に重要な意義をもつようになる生態, つまり生殖行動
と関連していることを示唆するが，実際の観察はそれ を見事に証明した。

シャーレの中での観察であるが, 砂底種 L. uranouchiensis は, 求愛行動を経た後, オスとメスが互いの脚 を抱えるように向き合って，腹と腹を合わせ交尾する (ventral to ventral position)（図 8 ). この際交尾中
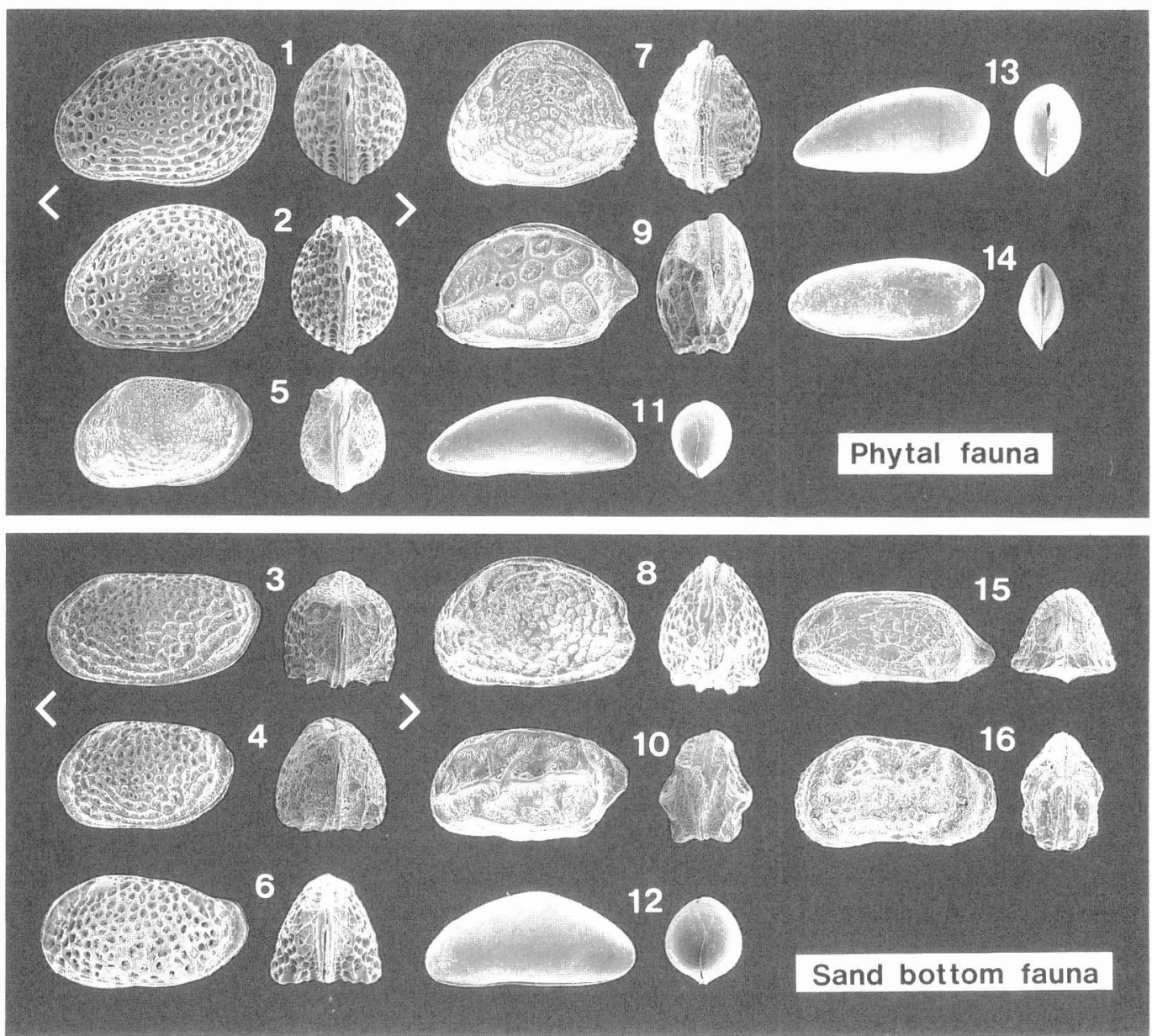

図 4 アマモ場に生息する介形虫の背甲の形態（左：左側方からみた図，右：尻側からみた図)

1 Loxoconcha japonica ( 7 ) x 39

$10 \quad H$. tricarinata $\times 53$

2 L. japonica (우) x39

L. uranouchiensis (व) $\times 39$

11 Cytherois ezoensis $\mathrm{x} 53$

L. uranouchiensis (우) $\times 39$

12 C. sp. $\mathrm{x} 53$

Loxocomiculum mutsuense $\mathrm{x} 34$

13 Paradoxostoma coniforme $\times 32$

6 Loxoconcha harimensis $\times 39$

$14 P$. setoense $\mathrm{x} 32$

7 Aurila munechikai $\times 32$

15 Semicytherura elongata $\times 53$

8 A. uranouchiensis $\times 28$

9 Hemicythenura Kajiyamai x53

16 Callistocythere rugosa $\times 45$ 


\begin{tabular}{|c|c|c|c|}
\hline & \multicolumn{2}{|c|}{ Shape of carapace } & \multirow{2}{*}{ species } \\
\hline & lateral view & posterior view & \\
\hline 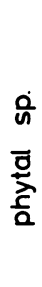 & circle & $\begin{array}{l}\text { rugby-ball } \\
\text { shape }\end{array}$ & $\begin{array}{l}\text { Loxoconcha japonica } \\
\text { Loxocorniculum mutsuense } \\
\text { Paradoxostoma coniforme } \\
P . \quad \text { setoense } \\
\text { Cytherois ezoensis } \\
\text { Hemicytherura kajiyamai } \\
\text { Aurila munechikai } \\
\text { (Xestoleberis hanaii) }\end{array}$ \\
\hline 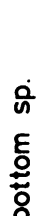 & rectangle & triangle & $\begin{array}{l}\text { Loxoconcha uranouchiensis } \\
\text { L. } \quad \text { bispinosa } \\
\text { L. Sp. } \\
\text { Aurila uranouchiensis } \\
\text { Hemicytherura tricarinata } \\
\text { Semicytherura elongata }\end{array}$ \\
\hline 뭄 & $\begin{array}{l}\text { elongate } \\
\text { rectangle }\end{array}$ & circle & $\begin{array}{l}\text { Cytherois sp. } \\
\text { Keijella bisanensis } \\
\text { Callistocythere rugosa } \\
\text { (Xestoleberis hanaii) }\end{array}$ \\
\hline
\end{tabular}

図 5 アマモ場の葉上種, 砂底種の背甲形態の分類 (KAMIYA, 1988a より引用)

のペアは底質上にごろっと横になるか，逆立ちするよ うな姿勢をとる。交接は一般に数分以上, 長い場合に は30分に及ぶ. 腹の平らなこの種の款形態はこの交尾 姿勢に都合が良い.つまり，腹と腹がぴたりと合わさ るのでオスとメスの生殖器の接触は短距離で斉む. こ のような格好での交尾は Keijella bisanensis にも認め られる.一方葉上種は, シャーレの底面または側面(実 際にはアマモ葉面）を這うメスの殼の側面にしがみつ いて求愛行動をしたオスがそのままの角度で生殖器を 伸ばし, 壳を半開きにしてふんばるメスと交尾する (ventral to lateral position)（図 9 ). 垂直な滑面上 では個体は脚で身体を支えていないかぎり落下するわ けであるが，この一見不自然な，無理のある姿勢は， 実は「交尾のたびに落下」というきわめて不都合な状 況を回避しうる交尾姿勢の一つなのである，交尾時間 が極端に短い（ 3 秒以内）こともこれに調和的である. そして葉上種の殻の形はこの姿勢にうってつけである. 立体的に考えれば明白なことだが, 殸の縁までスムー ズな曲面をもつので，オス・メスが斜めの角度で接し ても緑と縁が合わせ易く，ひいては生殖器が接し易い。 仮に砂底種のようにカドばっておれば斜めの角度では 緑が合わせられず, オスは L 字状に曲がる超長大の生 殖器を必要とするだろう。また斜めに切れ上がってい
るメスの款後部は, メスが葉面にしがみついたときに 葉面と生殖器の間に空間を生じるので, オスの生殖器 を受け入れ易い。総じて上手く出来ているのである.

このタイプの交尾様式は Paradoxostomaにも観察さ れる.

壳形態以外に, 既に触れたが, オスの生殖器の形態 も機能的である. Loxoconcha 葉上種は砂底種に比べ, 長い柄をもつ巨大な penis を有し（図 7 ), Paradoxostoma 属は起立時に先端が大きな角度で反転する penis をもつが，これらはいずれも ventral to lateral の（いわばいくら款形態を工夫しても無理のある）姿 勢での交尾に都合良いものである，また，葉上種，砂 底種をバケツの底においた時にもおもしろい行動の違 いがみられ, 葉上種は底に置かれた直後から活発に歩 き回り, 垂直なバケツの側面にでくわすとそれを一挙 によじのほり，以後水面近くをはいかいするが(この 傾向は特に Loxoconcha japonica で顕著), 砂底種は底 にとどまっている(図10).これは葉から落下した際の 葉上種の行動を示唆している可能性が高い. そして Loxoconcha 葉上種の脚先端に発達するかぎつめ状構 造（図11）は葉面をしっかり掝むという点で,この行 動，また先に述べたオスがメスにしがみつき，メスは 葉面にしがみつくという交尾行動に都合良いものかも 


\section{L. japonica}

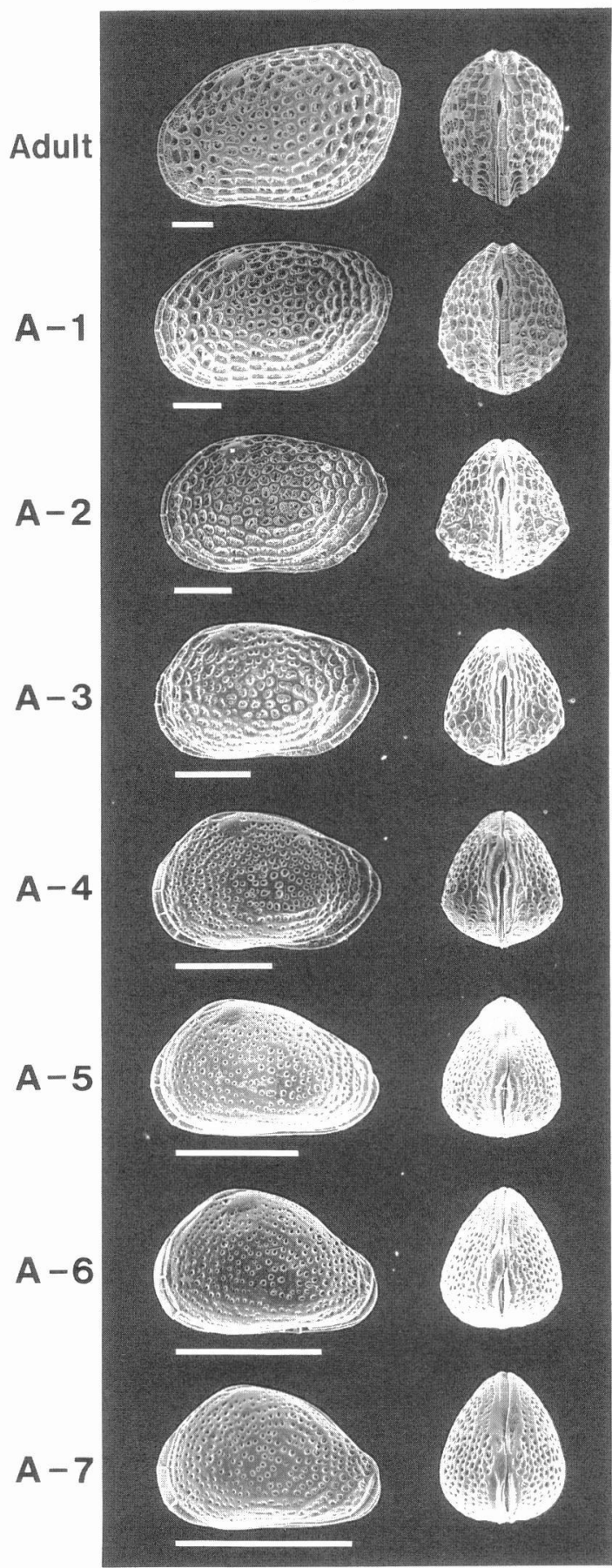

L. uranouchiensis
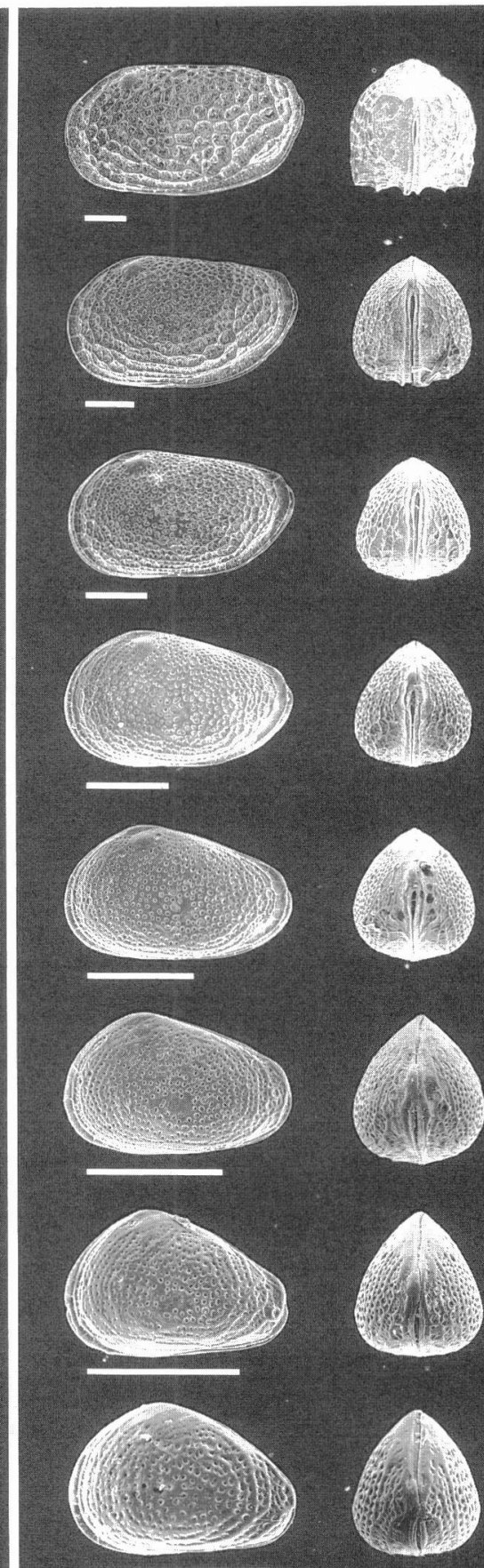

図 6 Loxoconcha japonica (葉上種) とL. uranouchiensis（砂底種）の個体発生における背甲形態の変化。 両種とも 7 回の脱皮を経て成体となる。

スケール・バーは $100 \mu \mathrm{m}$. (KAMIYA，1988aより引用) 


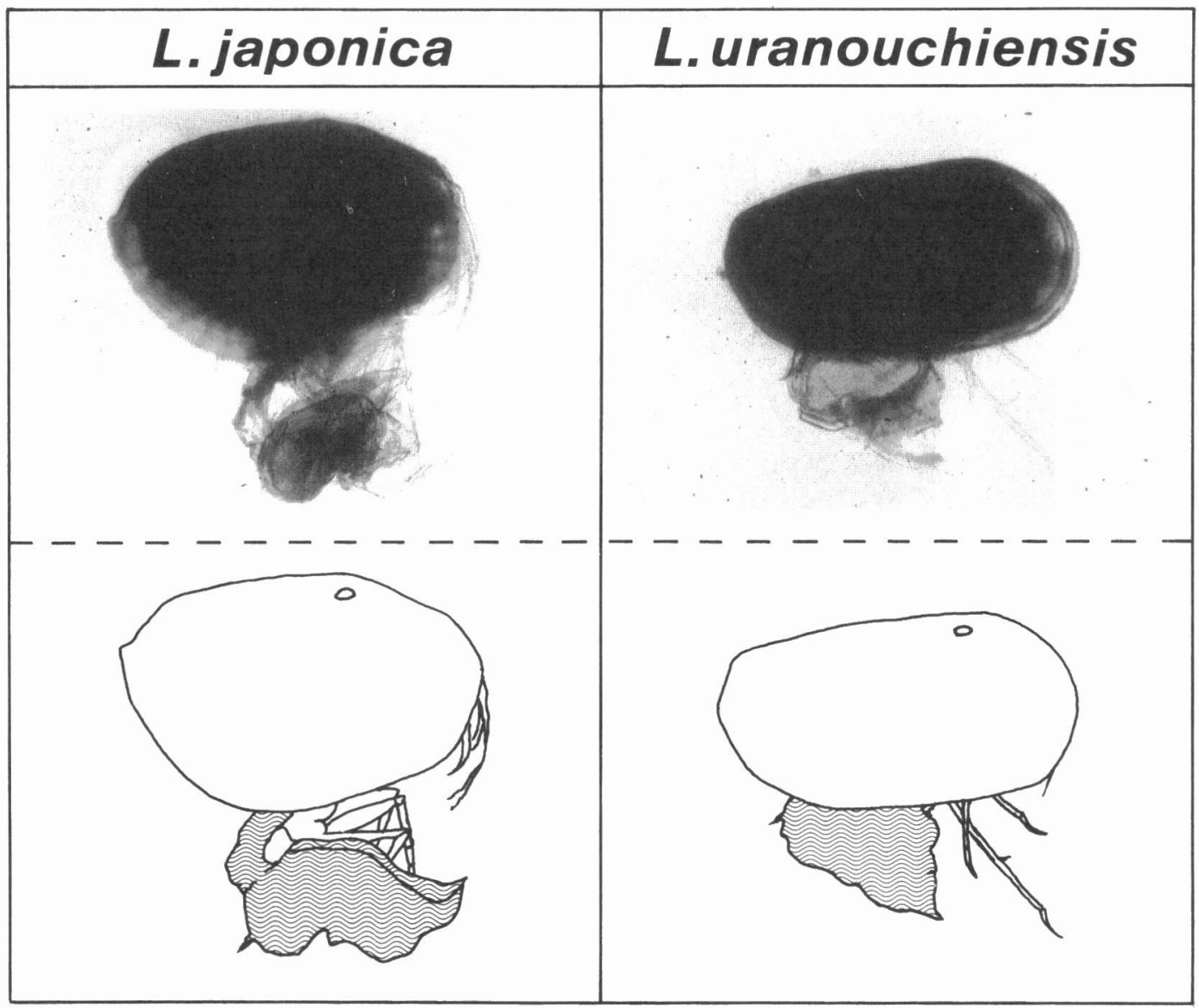

図 7 Loxoconcha japonica（葉上種）とL. uranouchiensis（砂底種）のオスの生殖器の形態.（KAMIYA, 1988aより引用)

知れない.

以上みてきたように，滑らかで垂直な葉面という棲 み場所の形状がもたらす物理的環境が葉上種の行動様 式，なかでも「交尾行動」を規制せざるを得ないため, それにともない葉上種の殼や軟体部の形態は特徵的な ものとなっているらしい。これに対し，交尾姿勢が自 由に採れる底質上では，交尾より通常の生活様式に関 連して形が決まる。軟泥（フロキュレント層）上に棲 む種類では安定のためか腹面の接地面積が大きくなつ ており，軟泥中をよく潜る種は細長く，流線型を採る 傾向にある (図12)。これは BENSON (1959) の指摘と 一致する。

以上は油壶湾アマモ場にみられた介形虫類の観察結 果である。ひとくちにアマモ場の群集と言っても, 実 は，いろいろな点で対照的な二つの群集が，そこでき
れいに分かれて生活している。一方がこれに対し，興 味深いことに, 岸よりの岩礁地に発達するピりヒバな どの樹状の海藻からは腹部の尖った種類 (Neonesidea, Loxocorniculum, Callistocythere etc.) と平らな種類（Robustaurila，Xestoleberis etc.）の両 方のタイプが産する。これは根元に近い葉と葉の間に デトリタスが付着しやすいため, 樹状の海藻が実際に は、海底底質上」と「滑らかな葉上」のふたつの夕イ プの棲み家を提供するためと考えられる。小さな介形 虫の理解には, あたりまえのことであるが, 彼らの立 場にたった考察が必要なのである. 


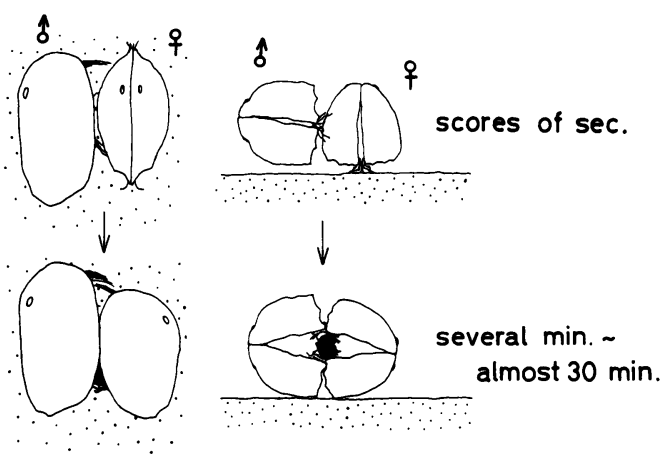

図 8 Loxoconcha uranouchiensis（砂底種）の性行 動。左：底面に対し上方からみた図, 右：底面 と平行にみた図。上図の求愛行動の後, 下図の 交尾行動に移る。底質の形状は便宜的に描いた。 (KAMIYA，1988aを修正)

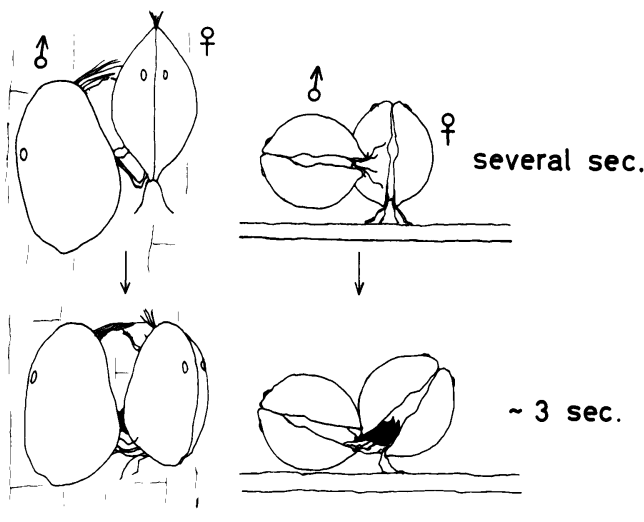

図 9 Loxoconcha japonica (葉上種) の性行動. 左： 底面（アマモ葉）に対し上方からみた図。右： 底面（アマモ葉）と平行にみた図。上図の求愛 行動の後, 下図の交尾行動に移る。底質 (アマ モ葉)の形状は便宜的に描いた。 (KAMIYA, 1988 aを修正)

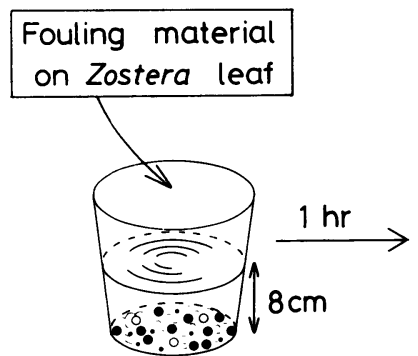

\section{Surface flocculent} sediment
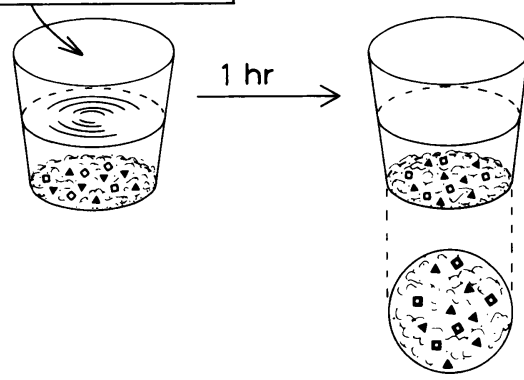

$24 \mathrm{hrs}$

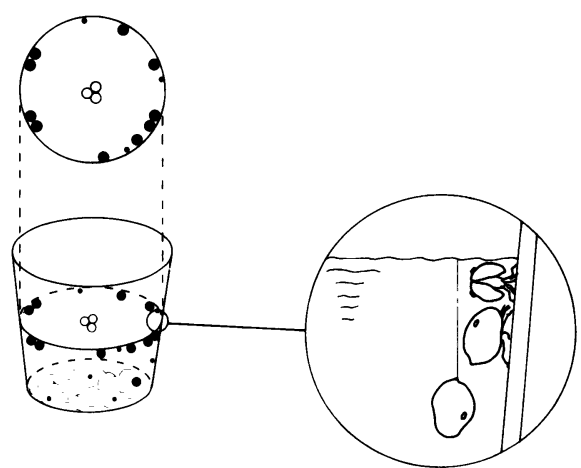

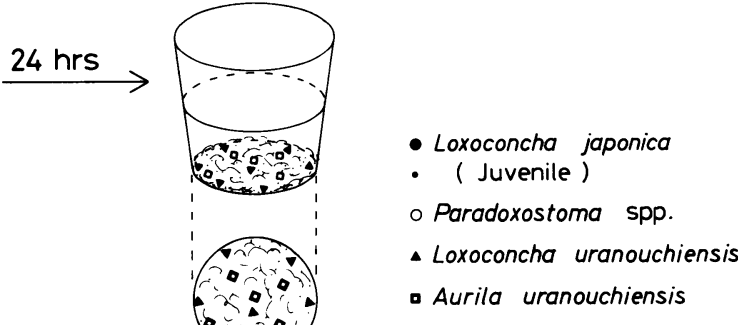

図10 バケツ底に置かれた時の葉上種（上闵）と砂底種（下図）の行動。記号ひとつひとつが各個体に対応。 (KAMIYA，1988aより引用) 

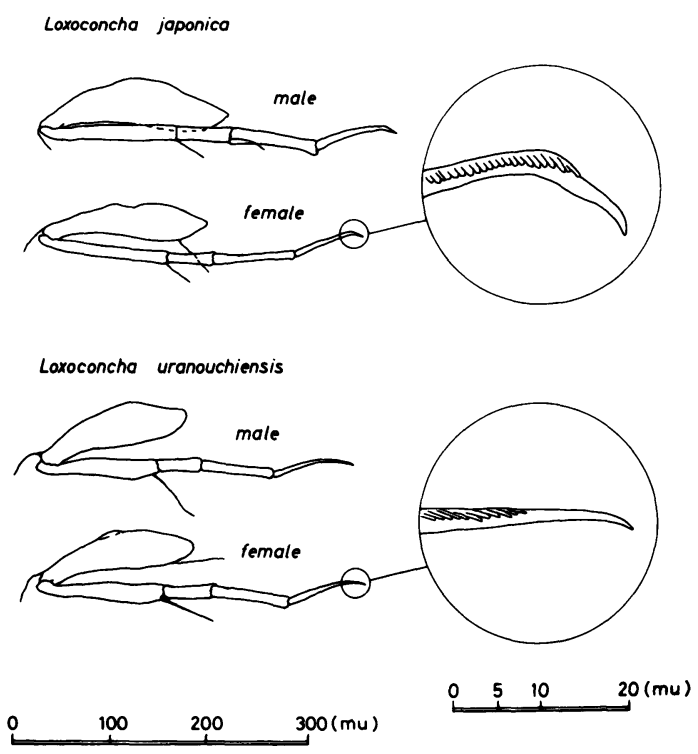

図11 Loxoconcha japonica（葉上種）とL. uranouchiensis（砂底種）の付属肢（第三胸肢）の形態. (KAMIYA, 1988aより引用)

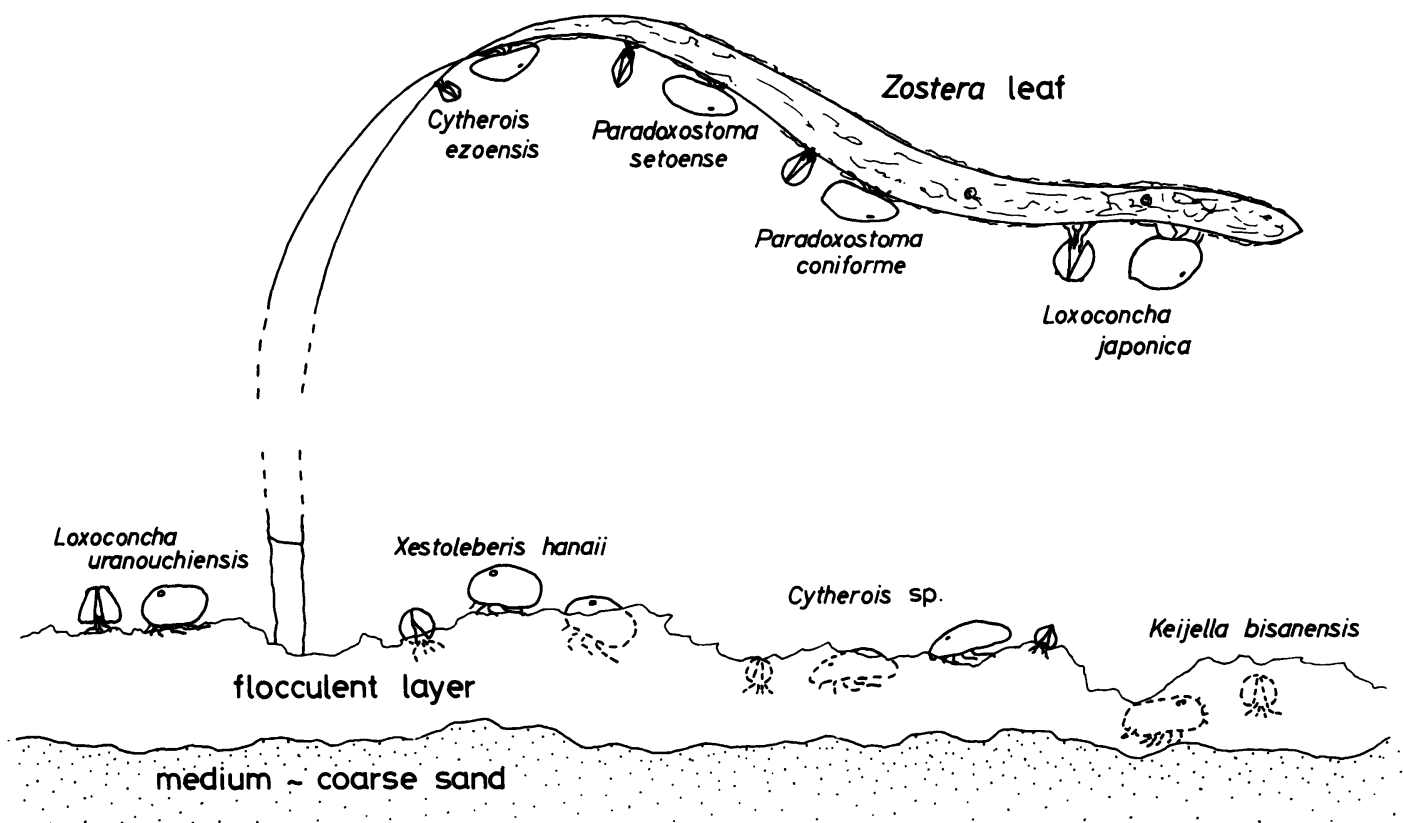

図12 アマモ場の葉上種, 砂底種の微視的な分布。(KAMIYA，1988aより引用） 


\section{他の藻場の介形虫群集}

油壼湾における観察結果の普遍性を確かめるべく, 他の藻場に産する介形虫の形態を調べたが, 結果は何 れもこれを支持するものであった。例えば，能登半島 西岸, 承見で採取したモズク, サクラノリなどの表面 の滑らかな海藻類からは腹部の尖った 4 種（Paradoxostoma, Xestoleberis, Hemicytherura) (図13)が得ら れ，七尾湾の石灰藻（ピリヒバ）からは腹の平らな 2 種 (Robustaurila, Xestoleberis) と腹の尖った 3 種 (Paradoxostoma, Callistocythere, Xestoleberis)の両 方のタイプが見つかる(図14)。また，赤道を隔てたオ ーストラリア木曜島（図15）のヒルムシロ科海草から は,やはり, 腹部の尖ったタイプから成る群集が得ら れた(図16)。Loxoconchaは世界中の浅海で最も繁栄 している属の一つで, その形態も多岐にわたるが,こ の群集に含まれるLoxoconcha georgei（図16-4）の 形態が油壳湾アマモ場のL. japonicaのそれと非常に 良く似ていることは機能形態の普遍性を物語るかなり 決定的な資料であると考えられる。

\section{おわりに}

どの交尾姿勢にどんな殻形態が適切であるかという 殼の機能形態については，既にMCGREGOR \& KES. LING（1969）がすばらしい考察を行っている。しかし 彼らの論文では，1) 側面から観た殻形態だけを問題 にしたため(殸のふくらみ，腹面の形などは無視），交 尾姿勢をも平面的にとらえることとなり，“ventralto-lateral”といった立体的な姿勢を考慮していない 点，2）交尾の姿勢と生息場所の関連までは考察して いない点，などに検討の余地があった。本研究はこれ らの点を考慮し，交尾を三次元的に考察し，それを生 息場所への適応という観点から論じるのに成功した初 めての研究である.

いろいろな観点から生活様式を観察してきた結果, 介形虫, 特に葉上種 Loxoconcha japonicaに接してい ると感ぜずにはいられないことは，この生物がまさに

「生殖」に重点を置いて理解すべき生物であるという 印象である。オスでは生殖器が全体の半分を占めよう かという軟体部，また収納する生殖器の形と交尾姿勢 を反映する殻形態にしてしかり。常に攻撃的ともいえ るほどメスに対して交尾をしかけ，終るとまたすぐ別

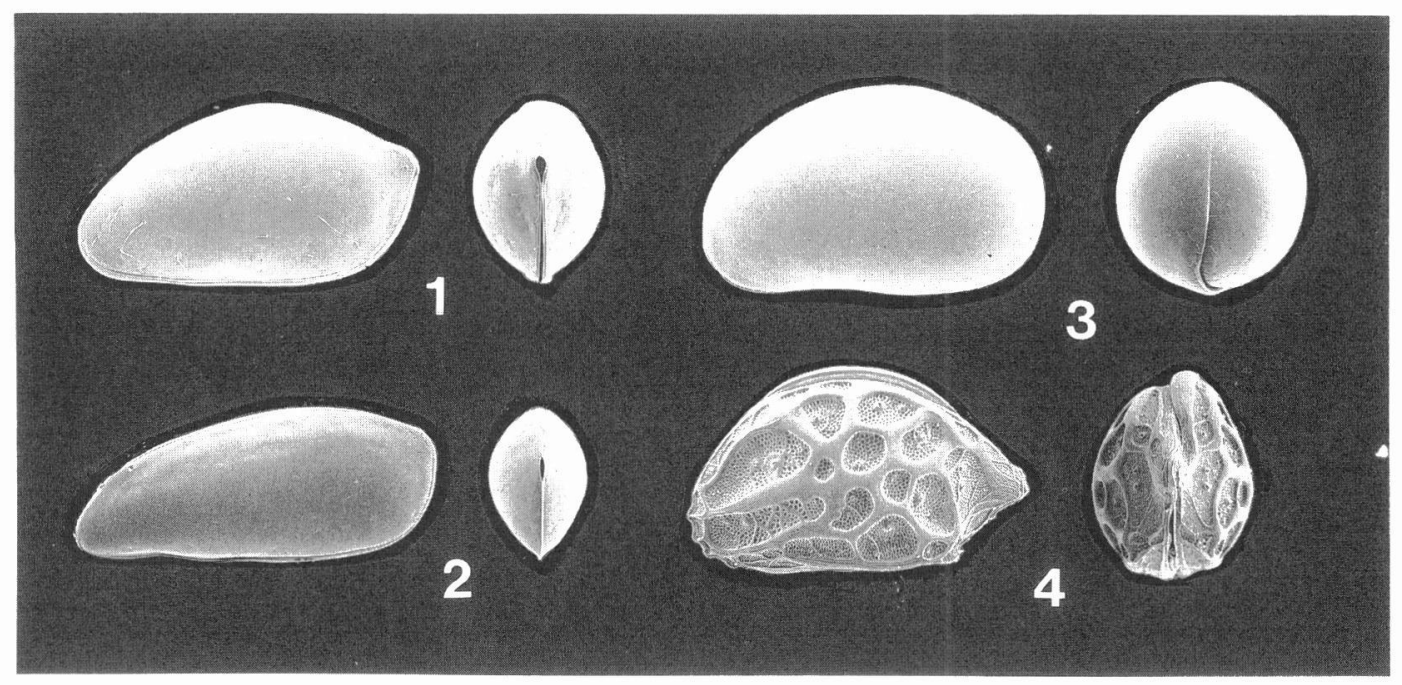

図13 能登半島水見海岸の葉上（モズク, サクラノリ）介形虫群集.

1 Paradoxostoma yatsui $\mathrm{x} 64$

$2 \quad$ P. coniforme $\mathrm{x} 57$

3 Xestoleberis hanaii $\mathrm{x} 53$

4 Hemicytherura kajiyamai $\times 90$ 


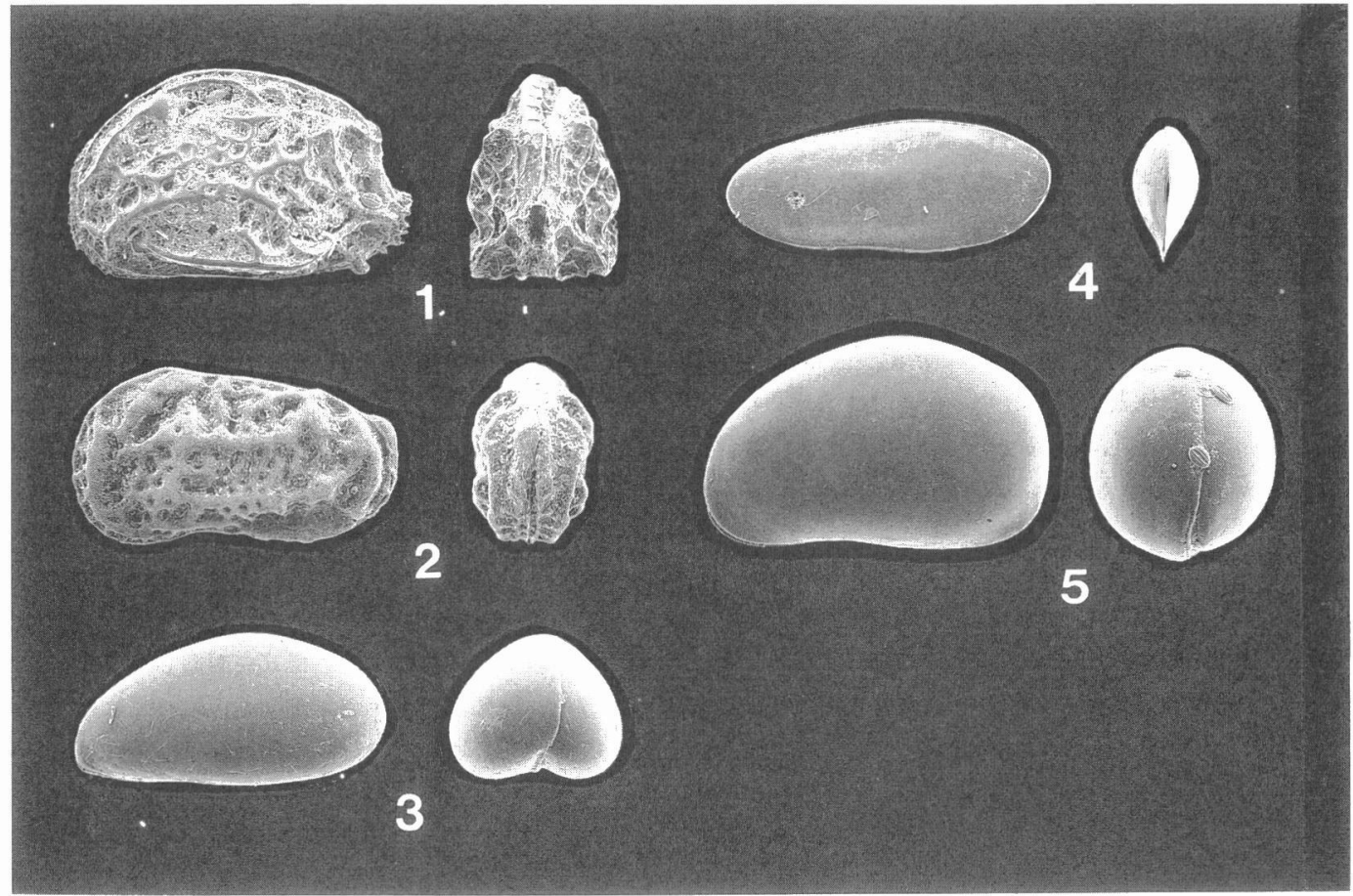

図14 能登半島七尾湾岩礁地の葉上(ピリヒバ) 介形虫群集.

1 Robustaurila ishizakii $\times 44$

2 Callistocythere undulatifacialis $\times 67$

3 Xestoleberis setouchiensis $\mathrm{x} 77$

Paradoxostoma setoense $\times 50$

5 Xestoleberis hanaii $\mathrm{x} 55$

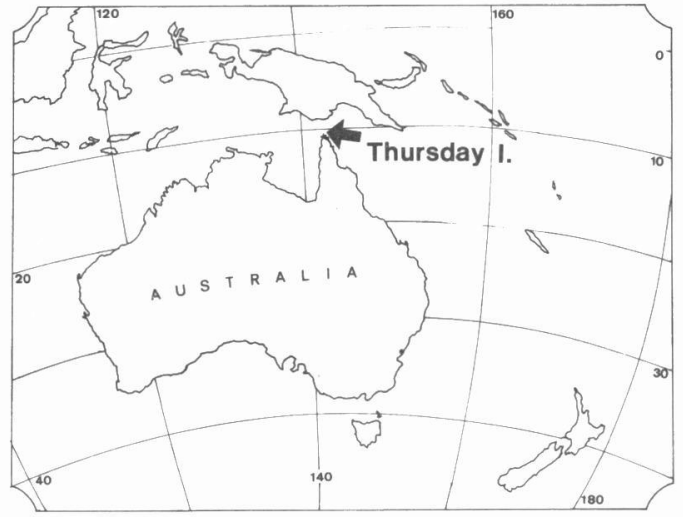

図15オーストラリア・木曜島位置図
のメスに挑旮オスの行動, それに関連した性比の問題 にしてしかり(詳しくは KAMIYA，1988b を参照).ア マモ群落には四季の変化があり，葉が枯れて脱落する 秋は葉上種にとって棲み家ごと流されていく危険な時 期であるが，群全体としてはこの時期を，ひたすら多 くの個体を生産し運の良いものが生き残るという「数 打ちゃ当たる」方式で乗り切り, 群落の安定期には少 数個体が効率よく生き延びて世代をつなぐ, という個 体群生態にしてしかりである（詳しくは KAMIYA, $1988 \mathrm{c}$ を参照)。これらは全て浮遊期を持たない直達発 生の介形虫がアマモ葉上という相当㛜しい環境で次世 代を残していくために採らざるを得ない，しかし見事 な戦略といえるだろう。別の言い方では, アマモ葉上 というのはLoxoconcha 属の介形虫ががんばって工夫 をするとなんとかやっていけるような丁度適度に苛酷 な環境なのであって，それにうまくパスした葉上種の 生活様式にはその工夫が浮き彫りになって表れている, 


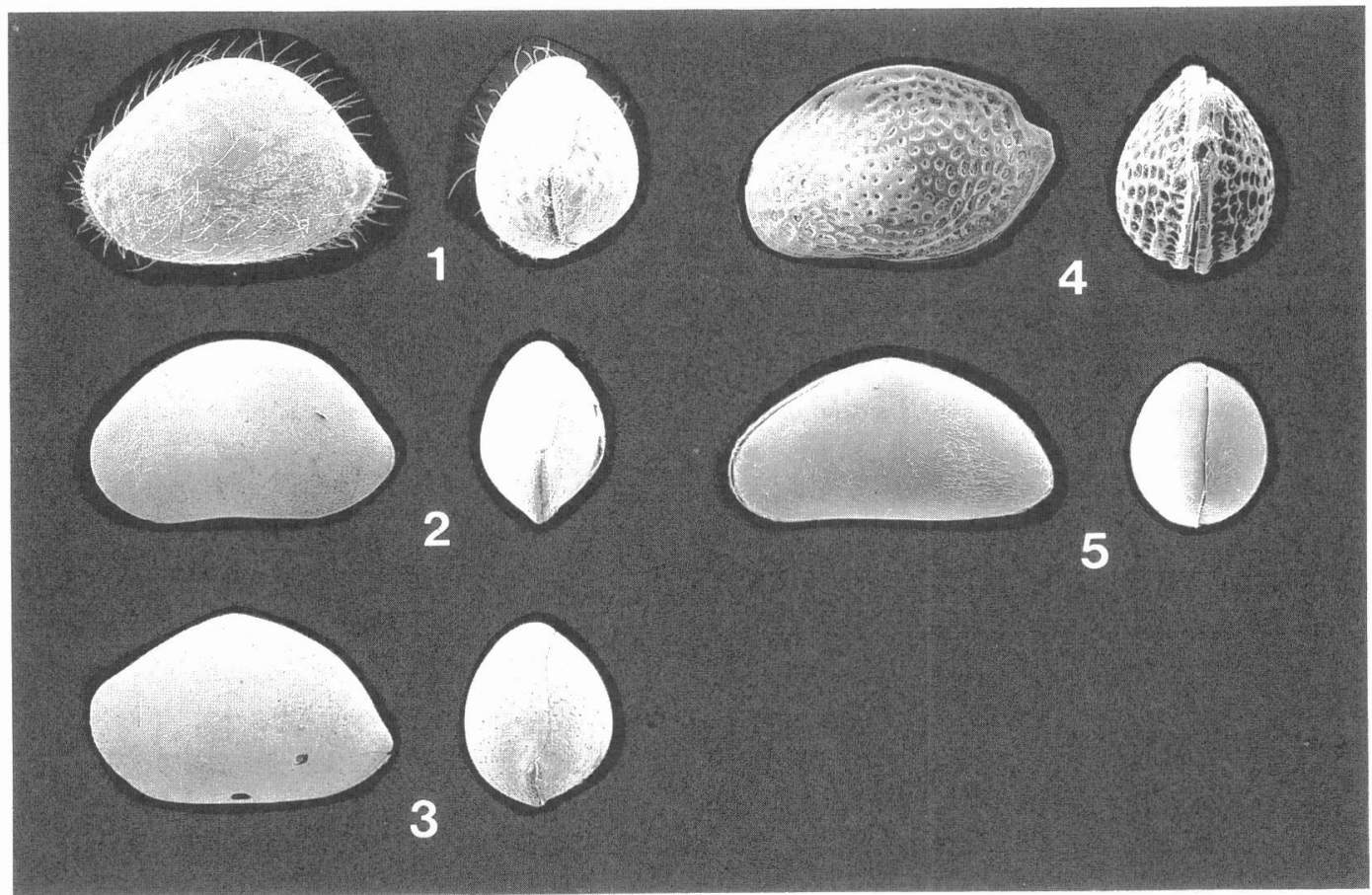

図16オーストラリア・木曜島の葉上（ヒルムシロ科の海草）介形虫群集.

1 Neonesidea guildertonensis? $\mathrm{x} 28$

2 Bairdoppilata bahlihaiensis? $\times 30$

3 Neonesidea rosaliae? x25

4 Loxoconcha georgei $\mathrm{x} 55$

5 Propontocypris sp. $\mathrm{x} 28$

とも言えるであろう。相対的に安定な環境である砂底 上に棲む同属異種 L. uranouchiensis との対照は鮮や かである。こうして（おそらく幸運も重なって）アマ モ場の調査を通して，介形虫の特性をうまく見いだす ことができた。この様な介形虫の適応がいつでも首尾 良くみられるとは思わないが，地道な調査が今後とも 介形虫の実体をひとつひとつあばいていくことはまち がいない. 生殖を中心とした生活様式（交尾姿勢，生 殖時期など）が化不からも読み取れるユニークな材料 である「介形虫」学の発展が期待される。

\section{謝 辞}

本研究は筆者が大学院時代に行った調査結果に, 若 干の追補資料を加えてまとめたものである。その間終 始指導, 教示いただいた東京大学花井哲郎名誉教授に 感謝する。東京大学速水格教授, 京都大学鎮西清高教
授, 静岡大学池谷仙之教授, 東京大学阿部勝巳博士に は折りに触れ有益な議論をしていただいた。東京大学 海洋研究所向井宏博士にはオーストラリアの藻場の試 料を提供していただき，またアマモおよび葉上動物の 生態について教示いただいた。東京大学理学部付属三 崎臨海実験所の方々には野外調查, 室内作業両面でた いへんお世話になった。向井宏博士，金沢大学小西健 二教授には粗稿を読んでいただいた。以上の方々に深 く感謝する。 


\section{文献}

BENSON, R. H., 1959. Ecology of recent ostracodes of the Todos Santos Bay Region, Baja California, Mexico. The Univ., Kansas Paleontol. Contr. Arthoropoda, 1:1-80.

CARBonel, P. and T. Holbian, 1988. The impact of organic matter on ostracods from an equatorial deltaic area, the Mahakam Delta Southeastern Kalimantan. In, Evolutionary biology of Ostracoda, ed. by T. HANAI, N. IKEYA and K. ISHIZAKI, Kodan-sha Scientific, Tokyo, pp. 353-366.

DANIELOPOL, D., W. Geiger, M. Tölderer-Farmer, C. Orellana and M. - N. Terrat, 1988. In search of Cypris and Cythere - A report of the evolutionary ecological project on limnic Ostracoda from the Mondsee (Austria). In, Evolutionary biology of Ostracoda, ed. by $\mathrm{T}$. HANAI, N. IKEYA and K. ISHIZAKI, Kodan-sha Scientific, Tokyo, pp. 485-500.

GoulD, S. J., 1974. The origin and function of "bizarre" structures : antler size and skull size in the "Irish Elk" Megaloceros giganteus. Evol., $28: 191-220$.

GRANT, R.E., 1975. Methods and conclusions in functional analysis:A reply. Lethaia, $8: 31$ 33.

KamiYA, T., 1988a. Morphological and ethological adaptations of Ostracoda to microhabitats in Zostera beds. In, Evolutionary biology of Ostracoda, ed. by T. HANAI, N. IKEYA and K. ISHIZAKI, Kodan-sha Scientific, pp. 303318.

KAmIYA, T., 1988b. Different sex-ratios in two Recent species of Loxoconcha (Ostracoda). Senckenbergiana lethaea, $68: 337-345$.

KamiYA, T., 1988c. Contrasting population ecology of two species of Loxoconcha (Ostracoda, Crustacea) in Recent Zostera beds: adaptive differences between phytal and bottom. dwelling species. Micropaleontol., 34:316-331.
KamiYA, T., 1989. Differences between the sensory organs of phytal and bottom-dwelling Loxoconcha (Ostracoda, Crustacea). J. Micro. palaeontol. (in press)

MCGREGOR, D. L. and R. V. KESLING, 1969. Copulatory adaptations in ostracods Part II. Adaptations in living ostracods. Contr. Mus. Paleont., Univ. Michigan, 22 : 221-239.

OKADA, Y., 1981. Development of cell arrangement in ostracod carapaces. Paleobiol., $7: 276$ -280 .

OKADA, Y., 1982a. Structure and cuticle formation of the reticulated carapace of the ostracode Bicornucythere bisanensis. Lethaia, 15: 85-101.

OKADA, Y., 1982b. Ultrastructure and pattern of the carapace of Bicornucythere bisanensis (Ostracoda, Crustacea). In, Studies on Japanese ostracoda, ed. by T. HANAI, Univ. Mus., Univ. Tokyo, Bull., 20:229-255.

ROSENFELD, A. and B. VeSPER, 1977. The variability of the sieve-pores in recent and fossil species of Cyprideis torosa (Jones, 1850) as an indicator for salinity and paleosalinity. In, Aspects of ecology and zoogeography of recent and fossil Ostracoda, ed. by H. LÖFFLER and D. DANIElOPOL, Dr. W. JUnK b. v. Publishers, The Hague, pp. 55-67.

RUDWICK, M. J.S., 1961. The feeding mechanism of the Permian brachiopod Prorichthofenia. Palaeontol., $3: 450-471$.

WILLIAMS, R., 1969. Ecology of Ostracoda from selcted marine intertidal localities on the coast of Anglesey. In, The taxonomy, morphology and ecology of recent Ostracoda, ed. by $\mathrm{J} . \mathrm{W}$. NEALE, OLIVER and BOYD, Edinburgh, pp. 299327.

1989 年 4 月 1 日受理 920 金沢市丸の内 $1-1$ 金沢大学理学部地学教室 神谷隆宏 